\title{
Roman Murawski
}

\section{TRUTH VS. PROVABILITY - PHILOSOPHICAL AND HISTORICAL REMARKS}

1. Since Plato, Aristotle and Euclid the axiomatic method was considered as the best method to justify and to organize mathematical knowledge. The first mature and most representative example of its usage in mathematics were Elements of Euclid. They established a pattern of a scientific theory and in particular a paradigm in mathematics. Since Euclid till the end of the nineteenth century mathematics was developed as an axiomatic (in fact rather a quasi-axiomatic) theory based on axioms and postulates. Proofs of theorems contained several gaps - in fact the lists of axioms and postulates were not complete, one freely used in proofs various "obvious" truths or refered to the intuition. Consequently proofs were only partially based on axioms and postulates. In fact proofs were informal and intuitive, they were rather demonstrations and the very concept of a proof was of a psychological (and not of a logical) nature. Note that almost no attention was paid to the precization and specification of the language of theories - in fact the language of the theories was simply the unprecise colloquial language. One should also note here that in fact till the end of the nineteenth century mathematicians were convinced that axioms and postulates should be simply true statements, hence sentences describing the real state of affairs (in the mathematical reality). It seems to be connected with Aristotle's view that a proposition is demonstrated (proved to be true) by showing that it is a logical consequence of propositions already known to be true. Demonstration was 
conceived here of as a deduction whose premises are known to be true and a deduction was conceived of as a chaining of immediate inferences.

Add that the Euclid's approach (connected with Platonic idealism) to the problem of the development of mathematics and the justification of its statements (which found its fulfilment in the Euclidean paradigm), i.e., justification by deduction (by proofs) from explicitly stated axioms and postulates, was not the only approach and method which was used in the ancient Greek (and later). The other one (call it heuristic) was connected with Democritean materialism. It was applied for example by Archimedes who used not only deduction but any methods, such as intuition or even experiments (not only mental ones), to solve problems. Though the Euclidean approach won and dominated in the history, one should note that it formed rather an ideal and not the real scientific practice of mathematicians. In fact rigorous, deductive mathematics was rather a rare phenomenon. On the contrary, intuition and heuristic reasoning were the animating forces of mathematical research practice. The vigorous but rarely rigorous mathematical activity produced "crises" (for example the pythagoreans' discovery of the incommensurability of the diagonal and side of a square, Leibniz's and Newton's problems with the explanation of the nature of infinitesimals, Fourier's "proof" that any function is representable in a Fourier series, antinomies connected with Cantor's imprecise and intuitive notion of a set).

Basic concepts underlying the Euclidean paradigm have been clarified on the turn of the nineteenth century. In particular the intuitive (and rather psychological in nature) concept of an informal proof (demonstration) was replaced by a precise notion of a formal proof and of a consequence. Several events and achievements contributed to the revision of the Euclidean paradigm, in particular the origin and the development of set theory (G. Cantor), arithmetization of analysis (A. Cauchy and K. Weierstrass, R. Dedekind), axiomatization of the arithmetic of natural numbers (G. Peano), non-Euclidean geometries (N. I. Lobachewsky, J. Bolayi, C. F. Gauss), axiomatization of geometry (M. Pasch, D. Hilbert), the development of mathematical logic (G. Boole, A. de Morgan, G. Frege, B. Russell). Beside those "positive" factors there was also a "negative" factor, viz., the discovery of paradoxes in set theory (C. Burali-Forti, G. Cantor, B. Russell) and of semantical antinomies (G.D. Berry, K. Grelling). They forced the revision of some basic ideas and stimulated in particular metamathematical investigations. One of the directions of those foundational investigations was the program of David Hilbert and his Beweistheorie. Note at the very beginning that "this program was never intended as a comprehensive philosophy 
of mathematics; its purpose was instead to legitimate the entire corpus of mathematical knowledge" (cf. Rowe, 1989, p. 200). Note also that Hilbert's views were changing over the years, but always took a formalist direction.

2. Hilbert sought to justify mathematical theories by means of formal systems, i.e., using the axiomatic method. He viewed the latter as holding the key to a systematic organization of any sufficiently developed subject. This idea was very well stated already in a letter of 29th December 1899 to G. Frege where Hilbert explained his motives of axiomatizing the geometry and wrote (cf. Frege 1976, p. 67):

I was forced to construct my systems of axioms by a necessity: I wanted to have a possibility to understand those geometrical propositions which in my opinion are the most important results of geometrical researches: that the Parallel Postulate is not a consequence of other axioms, and similarly for the Archimedean one, etc. ${ }^{1}$

In "Axiomatisches Denken" Hilbert wrote:

When we put together the facts of a given more or less comprehensive field of our knowledge, then we notice soon that those facts can be ordered. This ordering is always introduced with the help of a certain network of concepts in such a way that to every object of the given field corresponds a concept of this network and to every fact within this field corresponds a logical relation between concepts. The network of concepts is nothing else than the theory of the field of knowledge. ${ }^{2}$

By Hilbert the formal frames were contentually motivated. First-order theories were viewed by him together with suitable non-empty domains, Bereiche, which indicated the range of the individual variables of the theory and the interpretations of the nonlogical vocabulary. But Hilbert, as a mathematician, was not interested in establishing precisely the ontological status

\footnotetext{
${ }^{1}$ Ich bin zu der Aufstellung meines Systems von Axiomen durch die Not gezwungen: ich wollte die Möglichkeit zum Verständnis derjenigen geometrischen Sätze geben, die ich für die wichtigsten Ergebnisse der geometrischen Forschungen halte: dass das Parallelenaxiom keine Folge der übrigen Axiome ist, ebenso das Archimedische etc.

${ }^{2}$ Wenn wir die Tatsachen eines bestimmten mehr oder minder umfassenden Wissensgebiete zusammenstellen, so bemerken wir bald, daß diese Tatsachen einer Ordnung fähig sind. Diese Ordnung erfolgt jedesmal mit Hilfe eines gewissen Fachwerkes von Begriffen in der Weise, daß dem einzelnen Gegenstande des Wissensgebietes ein Begriff dieses Fachwerkes und jeder Tatsache innerhalb des Wissensgebietes eine logische Beziehung zwischen den Begriffen entspricht. Das Fachwerk der Begriffe ist nicht Anderes als die Theorie des Wissensgebietes.
} 
of mathematical objects. Moreover, one can say that his program was calling on people to turn their mathematical and philosophical attention away from the problem of the object of mathematical theories and turn it toward a critical examination of the methods and assertions of theories. On the other hand he was aware that once a formal theory has been constructed, it can admit various interpretations. Recall here his famous sentence from a letter to G. Frege quoted already above:

Yes, it is evident that one can treat any such theory only as a network or schema of concepts besides their necessary interrelations, and to think of basic elements as being any objects. If I think of my points as being any system of objects, for example the system: love, law, chimney-sweep [...], and I treat my axioms as [expressing] interconnections between those objects, then my theorems, e.g. the theorem of Pythagoras, hold also for those things. In other words: any such theory can always be applied to infinitely many systems of basic elements. ${ }^{3}$

The essence of the axiomatic study of mathematical truths was for him to clarify the position of a given theorem (truth) within the given axiomatic system and the logical interconnections between propositions. ${ }^{4}$

Hilbert sought to secure the validity of mathematical knowledge by syntactical considerations without appeal to semantic ones. The basis of his approach was the distinction between the unproblematic, 'finitistic' part of mathematics and the 'infinitistic' part that needed justification. Finitistic

\footnotetext{
${ }^{3} \mathrm{Ja}$, es ist doch selbsverständlich eine jede Theorie nur ein Fachwerk oder Schema von Begriffen nebst ihren nothwendigen Beziehungen zu einander, und die Grundelemente können in beliebiger Weise gedacht werden. Wenn ich unter meinen Punkten irgendwelche Systeme von Dingen, z.B. das System: Liebe, Gesetz, Schornsteinfeger [...] denke und dann nur meine sämtlichen Axiome als Beziehungen zwischen diesen Dingen annehme, so gelten meine Sätze, z.B. der Pythagoras auch von diesen Dingen. Mit anderen Worten: eine jede Theorie kann stets auf unendliche viele Systeme von Grundelementen angewandt werden.

${ }^{4}$ He wrote in $(1902 / 03$, p. 50): "Under the axiomatic study of any mathematical truth I understand a study whose aim is not to discover new or more general propositions with the help of given truths, but a study whose purpose is to determine a position of a given theorem within the system of known truths and their logical connections in such a way that one can clearly see which assumptions are necessary and sufficient to justify the considered truth." (Unter der axiomatischen Erforschung einer mathematischen Wahrheit verstehe ich eine Untersuchung, welche nicht dahin zieht, im Zusammenhange mit jener Wahrheit neue oder allgemeinere Sätze zu entdecken, sondern die vielmehr die Stellung jenes Satzes innerhalb des Systems der bekannten Wahrheiten und ihren logischen Zusammenhang in der Weise klarzulegen sucht, dass sich sicher angeben lässt, welche Voraussetzungen zur Begründung jener Wahrheit notwendig und hinreichend sind.)
} 


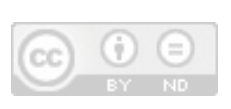

TRUTH VS. PROVABILITY ...

mathematics deals with so called real propositions, which are completely meaningful because they refer only to given concrete objects. Infinitistic mathematics on the other hand deals with so called ideal propositions that contain reference to infinite totalities. Hilbert proposed to base mathematics on finitistic mathematics via proof theory (Beweistheorie). The latter was planned as a new mathematical discipline in which one studies mathematical proofs by mathematical methods. Its main goal was to show that proofs which use ideal elements (in particular actual infinity) in order to prove results in the real part of mathematics always yield correct results. One can distinguish here two aspects: consistency problem and conservation problem. The consistency problem consists in showing (by finitistic methods, of course) that the infinitistic mathematics is consistent; the conservation problem consists in showing by finitistic methods that any real sentence which can be proved in the infinitistic part of mathematics can be proved also in the finitistic part. One should stress here the emphasis on consistency (instead of correctness).

To realize this program one should formalize mathematical theories (even the whole of mathematics) and then study them as systems of symbols governed by specified and fixed combinatorial rules. The advantage of this approach was the fact that references to ideal objects were replaced by reasonings of a purely finitary character, reasonings applied not to mathematical entities themselves but to the symbols of a formal language in which the concepts had been axiomatized, i.e., by syntactical considerations without appeal to the semantic ones. Another advantage was the fact that, as P. Bernays put it, "the problems and difficulties that present themselves in the foundations of mathematics can be transferred from the epistemological-philosophical to the properly mathematical domain".

The formal axiomatic system should satisfy three conditions: it should be complete, consistent and based on independent axioms. The consistency of a given system was the criterion for mathematical truth and for the very existence of mathematical objects. ${ }^{5}$ It was also presumed that any consistent theory would be categorical, that is, would (up to isomorphism) characterize a unique domain of objects. This demand was connected with the completeness.

\footnotetext{
${ }^{5}$ Cf. Hilbert's letter to G. Frege of 29th December 1899 where he claimed that: "If the arbitrary given axioms do not contradict one another with all their consequences, then they are true and the things defined by the axioms exist." (Wenn sich die willkürlich gesetzten Axiome nicht einander widersprechen mit sämtlichen Folgen, so sind sie wahr, so existieren die durch die Axiome definierten Dinge.) (cf. Frege, 1976, p. 66).
} 
The meaning and understanding of completeness by Hilbert plays a crucial rôle from the point of view of our subject. Note at the beginning that in the Grundlagen der Geometrie completeness was postulated as one of the axioms (the axiom was not present in the first edition, but was included first in the French translation and then in the second edition of 1903). In fact the axiom $\mathrm{V}(2)$ stated that: "Elements of geometry (i.e., points, lines and planes) form a system of things that does not admit any extension provided all the mentioned axioms are preserved". ${ }^{6}$ In Hilbert's lecture at the Congress at Heidelberg in 1904 (cf. 1905a) one finds such an axiom for the real numbers. Later there appears completeness as a property of a system. In lectures "Logische Principien des mathematischen Denkens" (1905, p. 13) Hilbert explains the demand of the completeness as the demand that the axioms suffice to prove all "facts" of the theory in question. He says: "We will have to demand that all other facts of the given field are consequences of the axioms." 7 On the other hand one can say that Hilbert's early conviction as to the solvability of every mathematical problem - expressed for example in his 1900 Paris lecture (cf. Hilbert 1901) and repeated in his opening address "Naturerkennen und Logik" (cf. Hilbert, 1930a) before the Society of German Scientists and Physicians in Königsberg in September 1930 - can be treated as informal reflection of his belief in completeness of axiomatic theories. In Paris Hilbert said:

The conviction of the solvability of any mathematical problem is for us a strong motive in this work; we hear the whole time the call: There is a problem, look for a solution. You can find it by a pure thinking; there is no Ignorabimus in the mathematics. ${ }^{8} \quad$ (Hilbert, 1901, p. 298)

6 "Die Elemente (Punkte, Geraden, Ebenen) der Geometrie bilden ein System von Dingen, welches bei Aufrechterhaltung sämtlicher genannten Axiome keiner Erweiterung mehr fähig ist."

In last editions of Grundlagen, beginning with the seventh edition from 1930, Hilbert replaced this axiom by the axiom of linear completeness stating that: "Points of a line form a system which admits no extension provided the linear order of the line (Theorem 6), the first congruence axioms and Archimedean axioms (i.e., axioms I1-2, II, III1, V1) are preserved." (Die Punkte einer Geraden bilden ein System, welches bei Aufrechterhaltung der linearen Anordnung (Satz 6), des ersten Kongruenzaxioms und des Archimedischen Axioms (d.h. der Axiome I1-2, II, III1, V1) keiner Erweiterung mehr fähig ist.)

${ }^{7}$ Wir werden verlangen müssen, dass alle übrigen Thatsachen des vorgelegten Wissensbereiches Folgerungen aus den Axiomen sind.

${ }^{8}$ Diese Überzeugung von der Lösbarkeit eines jeden mathematischen Problems ist uns ein kräftiger Ansporn während der Arbeit; wir hören in uns den steten Zuruf: $D a$ ist das Problem, suche die Lösung. Du kannst sie durch reines Denken finden; denn in der Mathematik gibt es kein Ignorabimus!. 
And in Königsberg he said:

For the mathematician there is no Ignorabimus, and, in my opinion, not at all for natural science either. [...] The true reason why [no one] has succeeded in finding an unsolvable problem is, in my opinion, that there is no unsolvable problem. In contrast to the foolish Ignorabimus, our credo avers: We must know, We shall know. ${ }^{9}$

In his 1900 Paris lecture Hilbert spoke about completeness in the following words:

When we are engaged in investigating the foundations of a science, we must set up a system of axioms which contains an exact and complete description of the relations subsisting between the elementary ideas of that science. The axioms so set up are at the same time the definitions of those elementary ideas; and no statement within the realm of the science whose foundations we are testing is held to be correct unless it can be derived from those axioms by means of a finite number of logical steps. ${ }^{10}$

(Hilbert, 1901, second problem, pp. 299-300)

One can assume that the phrase "exact and complete description" (genaue und vollständige Beschreibung) is equivalent to the requirement that this description is complete in the sense that it allows to decide the truth or falsity of every statement of the given theory. Semantically such completeness follows from categoricity, i.e., from the fact that any two models of a given axiomatic system are isomorphic; syntactically it means that every sentence or its negation is derivable from the given axioms. Hilbert's own axiomatizations were complete in the sense of being categorical. But notice that they were not first-order, indeed his axiomatization of geometry from Grundlagen as well as his axiomatization of arithmetic published in 1900 were second-order. Each of those system had a second-order Archimedean

${ }^{9}$ Für den Mathematiker gibt es kein Ignorabimus, und meiner Meinung nach auch für die Naturwissenschaft überhaupt nicht. [...] Der wahre Grund, warum es [niemand] nicht gelang, ein unlösbares Problem zu finden, besteht meiner Meinung nach darin, daß es ein unlösbares Problem überhaupt nicht gibt. Statt des törichten Ignorabimus heiße im Gegenteil unsere Losung: Wir müssen wissen, Wir werden wissen.

10 Wenn es sich darum handelt, die Grundlagen einer Wissenschaft zu untersuchen, so hat man ein System von Axiomen aufzustellen, welche eine genaue und vollständige Beschreibung derjenigen Beziehungen enthalten, die zwischen den elementaren Begriffen jener Wissenschaft stattfinden. Die aufgestellten Axiome sind zugleich die Definitionen jener elementaren Begriffe, und jede Aussage innerhalb des Bereiches der Wissenschaft, deren Grundlage wir prüfen, gilt uns nur dann als richtig, falls sie sich mittels einer endlichen Anzahl logischer Schlüsse aus den aufgestellten Axiomen ableiten läßt. 
axiom and both had a "completeness axiom" stating that the structure under consideration was maximal with respect to the remaining axioms. ${ }^{11}$

The demand discussed here would imply that a system of axioms complete in this sense is possible only for sufficiently advanced theories. On the other hand Hilbert called for complete systems of axioms also for theories being developed. In "Mathematische Probleme" he wrote:

[...] wherever mathematical concepts emerge from epistemological considerations or from geometry or from theories of science, mathematics aquires the task of investigating the principles lying at the basis of these concepts and defining $[\ldots]$ these through a simple and complete system of axioms. ${ }^{12}$

One should also add here that Hilbert admitted the possibility that a mathematical problem may have a negative solution, i.e., that one can show the impossibility of a positive solution on the basis of a considered axiom system. In "Mathematische Probleme" he wrote:

Occasionally it happens that we seek the solution under insufficient hypotheses or in an incorrect sense, and for this reason we do not succeed. The problem then arises: to show the impossibility of the solution under the given hypotheses, or in the sense contemplated [...] and we perceive that old and difficult problems [...] have finally found fully satisfactory and rigorous solutions, although in another sense than that originally intended. It is probably this important fact along with other philosophical reasons that give rise to the conviction $[\ldots]$ that every definite mathematical problem must necessarily be susceptible of an exact settlement, either in the form of an actual answer to the question asked, or by a proof of the impossibility of its solution and therewith the necessary failure of all attempts. ${ }^{13}$

11 Note that this axiom was not even properly a second-order axiom.

12 [...] wo immer von erkenntnistheoretischer Seite oder in der Geometrie oder aus den Theorien der Naturwissenschaft mathematische Begriffe auftauchen, erwächst der Mathematik die Aufgabe, die diesen Begriffen zugrunde liegenden Prinzipien zu erforschen und dieselben durch einfaches und vollständiges System von Axiomen [...] festzulegen.

13 Mitunter kommt es vor, daß wir die Beantwortung unter ungenügenden Voraussetzungen oder in unrichtigem Sinne erstreben und infolgedessen nicht zum Ziele gelangen. Es entsteht dann die Aufgabe, die Unmöglichkeit der Lösung des Problems unter den gegebenen Voraussetzungen und in dem verlangten Sinne nachzuweisen. [...] alte schwierige Probleme [...] eine völlig befriedigende und strenge Lösung gefunden haben. Diese merkwürdige Tatsache neben anderen philosophischen Gründen ist es wohl, welche in uns eine überzeugung entstehen lässt [...] daß ein jedes bestimmte mathematische Problem einer strengen Erledigung notwendig fähig sein müsse, sei es, daß es gelingt die Beantwortung der gestellten Frage zu geben, sei es, daß die Unmöglichkeit seiner Lösung and damit die Notwendigkeit des Mißlingens aller Versuche dargetan wird. 
In Hilbert's lectures from 1917-18 (cf. Hilbert, 1917-18) one finds completeness in the sense of maximal consistency, i.e., a system is complete if and only if for any non-derivable sentence, if it is added to the system then the system becomes inconsistent. ${ }^{14}$

In his lecture at the International Congress of Mathematicians in Bologna in 1928 Hilbert stated two problems of completeness, one for the first-order predicate calculus (completeness with respect to validity in all interpretations, hence the semantic completeness) and the second for a system of elementary number theory (formal completeness, in the sense of maximal consistency, i.e. Post-completeness, hence the syntactical completeness) (cf. Hilbert, 1930).

The emphasis on the finitary and syntactical methods together with the demand of (and belief in) the completeness of formal systems seems to be by Hilbert the source and reason of the fact that, as Gödel put it

[...] formalists considered formal demonstrability to be an analysis of the concept of mathematical truth and, therefore were of course not in a position to distinguish the two.

(Wang, 1974, p. 9)

Indeed, the informal concept of truth was not commonly accepted as a definite mathematical notion at that time. ${ }^{15}$ Gödel wrote in a crossed-out passage of a draft of his reply to a letter of the student Yossef Balas:

[...] a concept of objective mathematical truth as opposed to demonstrability was viewed with greatest suspicion and widely rejected as meaningless.

(Wang 1987, pp. 84-85)

It is worth comparing this with a remark of R. Carnap. He writes in his diary that when he invited A. Tarski to speak on the concept of truth at the September 1935 International Congress for Scientific Philosophy, "Tarski was very sceptical. He thought that most philosophers, even those working in modern logic, would be not only indifferent, but hostile to the explication of the concept of truth". And indeed at the Congress "[...] there was vehement

\footnotetext{
${ }^{14}$ Hilbert wrote in (1917-18, p. 152): "Let us now turn to the question of completeness. We want to call the system of axioms under consideration complete if we always obtain an inconsistent system of axioms by adding a formula which is so far not derivable to the system of basic formulas." (Wenden wir uns nun zu der Frage der Vollständigkeit. Wir wollen das vorgelegte Axiomen-System vollständig nennen, falls durch die Hinzufügung einer bisher nicht ableitbaren Formel zu dem System der Grundformeln stets ein widerspruchsvolles Axiomensystem entsteht.)

15 Note that there was at that time no precise definition of truth - this was given in 1933 by A. Tarski (cf. Tarski, 1933).
} 
opposition even on the side of our philosophical friends" (cf. Carnap, 1963, pp. 61-62).

All these explains in some sense why Hilbert prefered to deal in his metamathematics solely with the forms of the formulas, using only finitary reasoning which were considered to be save - contrary to semantical reasonings which were non-finitary and consequently not save. Non-finitary reasonings in mathematics were considered to be meaningful only to the extent to which they could be interpreted or justified in terms of finitary metamathematics. ${ }^{16}$

On the other hand there was no clear distinction between syntax and semantics at that time. Recall for example that, as indicated earlier, the axiom systems came by Hilbert often with a built-in interpretation. Add also that the very notions necessary to formulate properly the difference syntax-semantics were not available to Hilbert.

3. The problem of the completeness of the first-order logic, i.e., the fourth problem of Hilbert's Bologna lecture, was also posed as a question in the book by Hilbert and Ackermann Grundzüge der theoretischen Logik (1928). It was solved by Kurt Gödel in his doctoral dissertation (1929, cf. also 1930) where he showed that the first-order logic is complete, i.e., every true statement can be derived from the axioms. Moreover he proved that, in the first-order logic, every consistent axiom system has a model. More exactly Gödel wrote that by completeness he meant that "every valid formula expressible in the restricted functional calculus [...] can be derived from the axioms by means of a finite sequence of formal inferences". And added that this is equivalent to the assertion that "Every consistent axiom system [formalized within that restricted calculus] [...] has a realization" and to the statement that "Every logical expression is either satisfiable or refutable" (this is the form in which he actually proved the result). The importance of this result is, according to Gödel, that it justifies the "usual method of proving consistency".

In fact the completeness theorem shows in a sense an equivalence of truth and demonstrability, an equivalence of semantical and syntactical approach. It shows that the logical methods admitted by the notion of derivability are appropriate and sufficient. One should notice here that the notion of truth in a structure, central to the very definition of satisfiability or validity, was nowhere analyzed in either Gödel's dissertation or his published revision of it. There was in fact a long tradition of use of the informal notion of satisfiability (compare the work of Löwenheim, Skolem and others). ${ }^{17}$

${ }^{16}$ Cf. Gödel's letter to Hao Wang dated 7th December 1967 - see Wang 1974, p. 8.

${ }^{17}$ In Gödel's doctoral dissertation (1929) one finds the following explanation concerning 
Some months later, in 1930, Gödel solved three other problems posed by Hilbert in Bologna by showing that arithmetic of natural numbers and all richer theories are essentially incomplete (provided they are consistent) (cf. Gödel, 1931). It is interesting to see how did Gödel arrive at this result. Hao Wang, on the basis of his discussions with Gödel, reports this in the following way (see 1981):

[Gödel] represented real numbers by formulas [...] of number theory and found he had to use the concept of truth for sentences in number theory in order to verify the comprehension axiom for analysis. He quickly ran into the paradoxes (in particular, the Liar and Richard's) connected with truth and definability. He realized that truth in number theory cannot be defined in number theory and therefore his plan [...] did not work.

Gödel himself wrote on his discovery in a draft reply to letter dated 27th May 1970 from Yossef Balas, then a student at the University of Northern Iowa (cf. Wang, 1987, pp. 84-85). Gödel indicated there that it was precisely his recognition of the contrast between the formal definability of provability and the formal undefinability of truth that led him to his discovery of incompleteness. One finds also there the following statement:

$[\ldots]$ long before, I had found the correct solution of the semantic paradoxes in the fact that truth in a language cannot be defined in itself.

the considered problem: "Let $S$ be a system of functions $f_{1}, f_{2}, \ldots, f_{k}$ (all defined in the same universal domain), and of individuals (belonging to the same domain), $a_{1}, a_{2}, \ldots$, $a_{l}$, as well as propositional constants, $A_{1}, A_{2}, \ldots, A_{m}$. We say that this system, namely

$$
S=\left(f_{1}, f_{2}, \ldots, f_{k} ; a_{1}, a_{2}, \ldots, a_{l} ; A_{1}, A_{2}, \ldots, A_{m}\right),
$$

satisfies the logical expression if it yields a proposition that is true (in the domain in question) when it is substituted in the expression. From this we see at once what we must understand by satisfiable in a certain domain, by satisfiable alone (there is a domain in which the expression is satisfiable), by valid in a certain domain (the negation is not satisfiable), and by valid alone." (Wir sagen von einem System (sämtlich in demselben Denkbereich definierter) Funktionen, $f_{1}, f_{2}, \ldots, f_{k}$, und (ebenfalls demselben Denkbereich angehörenden) Individuen, $a_{1}, a_{2}, \ldots, a_{l}$, sowie Aussagen, $A_{1}, A_{2}, \ldots, A_{m}$ - von diesem System

$$
S=\left(f_{1}, f_{2}, \ldots, f_{k} ; a_{1}, a_{2}, \ldots, a_{l} ; A_{1}, A_{2}, \ldots, A_{m}\right)
$$

sagen wir, daß es den logischen Ausdruck erfülle, wenn es in denselben eingesetzt einen (in dem betreffenden Denkbereich) wahren Satz ergibt. Daraus erfolgt sich ohneweiteres, was unter erfüllbar in einem bestimmten Denkbereich, erfüllbar schlechthin (= es gibt einen Denkbereich, in dem der Ausdruck erfüllbar ist), allgemein giltig in einem bestimmten Denkbereich (= Negation nicht erfüllbar), allgemein giltig schlechthin verstanden werden soll.) 
On the base of this quotation it is sometimes argued that Gödel obtained the result on the undefinability of truth independently of A. Tarski (cf. Tarski, 1933; German translation - 1936, English translation - 1956). One should add that Tarski proving the undefinability of truth had the precise definition of this concept whereas Gödel used only an intuitive (and consequently imprecise) notion of truth. Hence there arises a problem: in which sense one can say that Gödel obtained the result of the undefinability of truth. ${ }^{18}$

Note also that Gödel was convinced of the objectivity of the concept of mathematical truth. In a latter to Hao Wang (cf. Wang, 1974, p. 9) he wrote:

I may add that my objectivist conception of mathematics and metamathematics in general, and of transfinite reasoning in particular, was fundamental also to my other work in logic. How indeed could one think of expressing metamathematics in the mathematical systems themselves, if the latter are considered to consist of meaningless symbols which acquire some substitute of meaning only through metamathematics $[\ldots]$ it should be noted that the heuristic principle of my construction of undecidable number theoretical propositions in the formal systems of mathematics is the highly transfinite concept of 'objective mathematical truth' as opposed to that of 'demonstrability' (cf. M. Davis, The Undecidable, New York 1965, p. 64 where I explain the heuristic argument by which I arrive at the incompleteness results), with which it was generally confused before my own and Tarski's work.

In this situation one should ask why Gödel did not mention the undefinability of truth in his writings. In fact, Gödel even avoided the terms "true" and "truth" as well as the very concept of being true (he used the term "richtige Formel" and not the term "wahre Formel"). In the paper "Über formal unentscheidbare Sätze ...' (1931) the concept of a true formula occurs only at the end of Section 1 where Gödel explains the main idea of the proof of the first incompleteness theorem (but again the term "inhaltlich richtige Formel" and not the term "wahre Formel" appears here). Indeed, talking about the construction of a formula which should express its own unprovability invokes the interpretation of the formal system. At the very end of the introductory section one finds the following remarks:

The method of proof just explained can clearly be applied to any formal system that, first, when interpreted as representing a system of notions and propositions, has at its disposal sufficient means of expression to

\footnotetext{
18 For the problem of the priority in proving the undefinability of the concept of truth see Woleński (1991) and Murawski (1998).
} 
define the notions occurring in the argument above (in particular, the notion "provable formula") and in which, second, every provable formula is true in the interpretation considered. The purpose of carrying out the above proof with full precision in what follows is, among other things, to replace the second of the assumptions just mentioned by a purely formal and much weaker one. ${ }^{19} \quad$ (Gödel, 1931, pp. 175-176;

English translation: Gödel, Collected Works, vol. I, p. 151)

[Add that the "purely formal and much weaker" assumption mentioned by Gödel was the assumption of the $\omega$-consistency, i.e., the assumption that for any formula $\varphi(x)$ with one free variable, if in the considered theory the sentences

$$
\varphi(0), \varphi(1), \varphi(2), \ldots, \varphi(n), \ldots \quad(n \in \mathbf{N})
$$

are provable then the formula $\exists x \neg \varphi(x)$ is not provable in it.]

On the other hand the term "truth" occurred in Gödel's lectures on the incompleteness theorems at the Institute for Advanced Study in Princeton in the spring of $1934 .{ }^{20}$ He discussed there, among other things, the relation between the existence of undecidable propositions and the possibility of defining the concept "true (false) sentence" of a given language in the language itself. Considering the relation of his arguments to the paradoxes, in particular to the paradox of "The Liar", Gödel indicates that the paradox disappears when one notes that the notion "false statement in a language $B$ " cannot be expressed in $B$. Even more, 'the paradox can be considered as a proof that "false statement in $B$ " cannot be expressed in B.' In the footnote 25 (added to the version published in Davis, 1965) Gödel wrote:

For a closer examination of this fact see A. Tarski's papers published in: Trav. Soc. Sci. Lettr. de Varsovie, Cl. III, No. 34, 1933 (Polish) (translated in: Logic, Semantics, Metamathematics. Papers from 1923 to 1938 by A. Tarski, see in particular p. $247 \mathrm{ff}$.) and in Philosophy and Phenom. Res. 4 (1944), pp. 341-376. In these two papers the concept of truth relating to sentences of a language is discussed systematically. See also: R. Carnap, Mon. Hefte f. Math. u. Phys. 4 (1934), p. 263.

\footnotetext{
${ }^{19}$ Die eben auseinandergesetzte Beweismethode läßt sich offenbar auf jedes formale System anwenden, das erstens inhaltlich gedeutet über genügend Ausdrucksmittel verfügt, um die in der obigen Überlegung vorkommenden Begriffe (insbesondere den Begriff "beweisbare Formel") zu definieren, und in dem zweitens jede beweisbare Formel auch inhaltlich richtig ist. Die nun folgende exakte Durchführung des obigen Beweises wird unter anderem die Aufgabe haben, die zweite der eben angeführten Voraussetzungen durch eine rein formale und weit schwächere zu ersetzen.

20 Notes of Gödel's lectures taken by S. C. Kleene and J. B. Rosser were published in Davis' book in 1965 (cf. Gödel, 1934).
} 
The reasons for the incompleteness results were also explicitly mentioned in Gödel's reply to a letter of A.W. Burks. This reply is quoted in von Neumann's Theory of Self-Reproducing Automata. Gödel wrote:

I think the theorem of mine which von Neumann refers to is not that on the existence of undecidable propositions or that on the length of proofs but rather the fact that a complete epistemological description of a language $\mathrm{A}$ cannot be given in the same language $\mathrm{A}$, because the concept of truth of sentences of A cannot be defined in A. It is this theorem which is the true reason for the existence of the undecidable propositions in the formal systems containing arithmetic. I did not, however, formulate it explicitly in my paper of 1931 but only in my Priceton lectures of 1934 . The same theorem was proved by Tarski in his paper on the concept of truth published in 1933 in Act. Soc. Sci. Lit. Vars., translated on pp. 152-278 of Logic, Semantics and Metamathematics.

(pp. 55-56)

What were the reasons of avoiding the concept of truth by Gödel? An answer can be found in a crossed-out passage of a draft of Gödel's reply to a letter of the student Yossef Balas (mentioned already above). Gödel wrote there:

However in consequence of the philosophical prejudices of our times 1. nobody was looking for a relative consistency proof because [it] was considered axiomatic that a consistency proof must be finitary in order to make sense, 2. a concept of objective mathematical truth as opposed to demonstrability was viewed with greatest suspicion and widely rejected as meaningless.

Hence it leads us to the conclusion formulated by S. Feferman in (1984) in the following way:

$[\ldots]$ Gödel feared that work assuming such a concept [i.e., the concept of mathematical truth - R.M.] would be rejected by the foundational establishment, dominated as it was by Hilbert's ideas. Thus he sought to extract results from it which would make perfectly good sense even to those who eschewed all non-finitary methods in mathematics.

Though he tried to avoid concepts not accepted by the foundational establishment, Gödel's own philosophy of mathematics was in fact platonist. He was convinced that:

It was the anti-Platonic prejudice which prevented people from getting my results. This fact is a clear proof that the prejudice is a mistake.

(Wang Hao, 1996, p. 83) 
Note that A. Tarski was free of such limitations. In fact in the LvovWarsaw School no restrictive initial preconditions were assumed before the proper investigation could start. The main demands were clarity, antispeculativeness and scepticism towards many fundamental problems of traditional philosophy. The principal method that should be used was logical analysis. The Lvov-Warsaw School was not so radical in its criticism of metaphysics as the Vienna Circe. ${ }^{21}$

Tarski pointed out on many occasions that mathematical and logical research should not be restricted by any general philosophical views. In particular he wrote in (1930):

In conclusion it should be noted that no particular philosophical standpoint regarding the foundations of mathematics is presupposed in the present work.

And in (1954) he wrote:

As an essential contribution of the Polish school to the development of metamathematics one can regard the fact that from the very beginning it admitted into metamathematical research all fruitful methods, whether finitary or not.

Hence Tarski, though indicating his sympathies with nominalism, freely used in his logical and mathematical studies the abstract and general notions that a nominalist seeks to avoid.

It is known that Tarski showed not only the undefinability but - and this is his main merit here - he gave the precise inductive definition of satisfiability and truth. In connection with this one should ask whether Gödel saw the necessity to give an analysis of the concept of truth (note that in his doctoral dissertation Über die Vollständigkeit des Logikkalküls (1929) and in his paper 'Die Vollständigkeit der Axiome des logischen Funktionenkalküls' (1930) on the completeness of the first-order predicate calculus the notion of the validity was understood in an informal way what was in fact a long tradition - cf. Löwenheim and Skolem). The answer is affirmative. Indeed, in a letter to R. Carnap of 11th September 1932 he wrote:

Ich werde auf Grund dieses Gedankens im II. Teil meiner Arbeit eine Definition für 'wahre' geben und ich bin der Meinung, daß sich die Sache anders nicht machen läßt und daß man den höheren Induktionenkalkül nicht semantisch [d.h. damals syntaktisch!] auffassen kann. ${ }^{22}$

${ }^{21}$ See, for example, Woleński (1989) and (1995).

${ }^{22}$ Quotation according to Köhler, 1991. 
Köhler explains in (1991) that "II. Teil meiner Arbeit" means here the joint project of Gödel together with A. Heyting to write a survey of the current investigations in mathematical logic for Springer-Verlag (Berlin). Heyting wrote his part while the part by Gödel was never written (the reasons were his problems with the health). One can assume that Gödel planned to develop there a theory of truth based on the set theory.

Gödel's theorem on the completeness of first-order logic and his discovery of the incompleteness phenomenon together with the undefinability of truth vs. definability of formal demonstrability showed that formal provability cannot be treated as an analysis of truth, that the former is in fact weaker than the latter. It was also shown in this way that Hilbert's dreams to justify classical mathematics by means of finitistic methods cannot be fully realized. Those results together with Tarski's definition of truth (in the structure) and Carnap's work on the syntax of a language led also to the establishing of syntax and semantics in the 1930s.

On the other hand it should be added that Gödel shared Hilbert's "rationalistic optimism" (to use Hao Wang's term) insofar as informal proofs were concerned. In fact Gödel retained the idea of mathematics as a system of truth, which is complete in the sense that "every precisely formulated yes-orno question in mathematics must have a clear-cut answer" (cf. Gödel, 1970). He rejected however - in the light of his incompleteness theorem - the idea that the basis of these truths is their derivability from axioms. In his Gibbs lecture of 1951 Gödel distinguished between the system of all true mathematical propositions from that of all demonstrable mathematical propositions, calling them, respectively, mathematics in the objective and subjective sense. He claimed also that it is objective mathematics that no axiom system can fully comprise.

4. Gödel's incompleteness theorems and in particular his recognition (before Tarski) of the undefinability of the concept of truth indicated a certain gap in Hilbert's programme and showed in particular, roughly speaking, that (full) truth cannot be established (achieved) by provability and, generally, by syntactic means. The former can be only approximated by the latter. Hence there arose a problem: how should one extend Hilbert's finitistic point of view?

Hilbert in his lecture in Hamburg in December 1930 (cf. Hilbert, 1931) proposed to admit a new rule of inference to be able to realize his program. This rule is similar to the $\omega$-rule, but it has rather informal character and a system obtain by admitting it would be semi-formal. In fact Hilbert pro- 
posed that whenever $A(z)$ is a quantifier-free formula for which it can be shown (finitarily) that $A(z)$ is a correct (richtig) numerical formula for each particular numerical instance $z$, then its universal generalization $\forall x A(x)$ may be taken as a new premise (Ausgangsformel) in all further proofs.

In Preface to the first volume of Hilbert and Bernays' monograph Grundlagen der Mathematik (1934/1939) Hilbert wrote:

$[\ldots]$ the occasionally held opinion, that from the results of Gödel follows the non-executability of my Proof Theory, is shown to be erroneous. This result showes indeed only that for more advanced consistency proofs one must use the finite standpoint in a deeper way than is necessary for the consideration of elementary formalism. ${ }^{23}$

Gödel pointed in many places that new axioms are needed to settle both undecidable arithmetical and set-theoretic propositions. In the footnote $48^{a}$ (evidently an afterthought) to (1931) he wrote:

As will be shown in Part II of this paper, the true reason for the incompleteness inherent in all formal systems of mathematics is that the formation of ever higher types can be continued into the transfinite $[\ldots]$ while in any formal system at most denumerably many of them are available. For it can be shown that the undecidable propositions constructed here become decidable whenever appropriate higher types are added (for example, the type $\omega$ to the system P). An analogous situation prevails for the axiom system of set theory. ${ }^{24}$

(English translation taken from Heijenoort, 1967, p. 610)

In (193?), handwritten notes in English, evidently for a lecture, one finds the following words of Gödel:

[...] number-theoretic questions which are undecidable in a given formalism are always decidable by evident inferences not expressible in

${ }^{23}[\ldots]$ die zeitweilig aufgekommene Meinung, aus gewissen neueren Ergebnissen von Gödel folge die Undurchführbarkeit meiner Beweistheorie, als irrtümlich erwiesen ist. Jenes Ergebnis zeigt in der Tat auch nur, daß man für die weitergehenden Widerspruchsfreiheitsbeweise den finiten Standpunkt in einer schärferen Weise ausnutzen muß, als dieses bei der Betrachtung der elementaren Formalismen erforderlich ist.

${ }^{24}$ Der wahre Grund für die Unvollständigkeit, welche allen formalen Systemen der Mathematik anhaftet, liegt, wie im II. Teil dieser Abhandlung gezeigt werden wird, darin, daß die Bildung immer höcherer Typen sich ins Transfinite fortsetzen läßt [...] während in jedem formalen System höchstens abzählbar viele vorhanden sind. Man kann nämlich zeigen, daß die hier aufgestellten unentscheidbaren Sätzen durch Adjunktion passender höcherer Typen (z.B. des Types $\omega$ zum System $P$ ) immer entscheidbar werden. Analoges gilt auch für das Axiomensystem der Mengenlehre. 
the given formalism. As to the evidence of these new inferences, they turn out to be exactly as evident as those of the given formalism. So the result is rather that it is not possible to formalise mathematical evidence even in the domain of number theory, but the conviction about which Hilbert speaks [i.e., the conviction of the solvability of every well formulated mathematical problem - R.M.] remains entirely untouched. Another way of putting the result is this: It is not possible to mechanise mathematical reasoning, i.e., it will never be possible to replace the mathematician by a machine, even if you confine yourself to numer-theoretic problems.

(p. 164)

In $(1931 ?$, p. 35) he stated that "[...] there are number-theoretic problems that cannot be solved with number-theoretic, but only with analytic or, respectively, set-theoretic methods". ${ }^{25}$ And in (1933, p. 48) he wrote: "there are arithmetic propositions which cannot be proved even by analysis but only by methods involving extremely large infinite cardinals and similar things". In (1951) Gödel stated that:

In order to prove the consistency of classical number theory (and a fortiori of all stronger systems) certain abstract concepts (and the directly evident axioms referring to them) must be used, where "abstract" means concepts which do not refer to sense objects, of which symbols are a special kind. [...] Hence it follows that there exists no rational justification of our precritical belief concerning the applicability and consistency of classical mathematics (nor even its undermost level, number theory) on the basis of a syntactical interpretation. (p. 318)

In (1970) Gödel proposed "cultivating (deepening) knowledge of the abstract concepts themselves which lead to the setting up of these mechanical systems". In (1972) (this paper was a revised and expanded English version of (1958)) Gödel claimed that concrete finitary methods are insufficient to prove the consistency of elementary number theory and some abstract concepts must be used in addition. He wrote:

Since finitary mathematics is defined [...] as the mathematics of concrete intuition, this seems to imply that abstract concepts are needed for the proof of consistency of number theory. [...] By abstract concepts, in this context, are meant concepts which are essentially of the second or higher level, i.e., which do not have as their content properties or relations of concrete objects (such as combinations of symbols), but

${ }^{25}[\ldots]$ es [gibt] zahlentheoretische Probleme, die sich nicht mit zahlentheoretischen sondern nur mit analytischen bzw. mengentheoretischen Hilfsmitteln lösen lassen. 
rather of thought structures or thought contents (e.g., proofs, meaningful propositions, and so on), where in the proofs of propositions about these mental objects insights are needed which are not derived from a reflection upon the combinatorial (space-time) properties of the symbols representing them, but rather from a reflection upon the meanings involved.

(pp. 271-273)

In the paper (1946) Gödel explicitely called for an effort to use progressively more powerful transfinite theories to derive new arithmetical theorems. He wrote there:

Let us consider, e.g., the concept of demonstrability. It is well known that, in whichever way you make it precise by means of a formalism, the contemplation of this very formalism gives rise to new axioms which are exactly as evident and justified as those with which you started, and that this process of extension can be iterated into the transfinite. So there cannot exist any formalism which would embrace all these steps; but this does not exclude that all these steps (or at least all of them which give something new for the domain of propositions in which you are interested) could be described and collected together in some non-constructive way.

(p. 151)

These remarks correspond with the words of $\mathrm{R}$. Carnap who wrote in (1934):

[...] all that is mathematical can be formalized; yet the whole of mathematics cannot be grasped by one system but an infinite series of still richer and richer languages is necessary. ${ }^{26}$

(p. 274)

One can compare the above remarks with those of Turing from his paper (1939). In the introduction to this paper Turing wrote: ${ }^{27}$

The well-known theorem of Gödel (1931) shows that every system of logic is in a certain sense incomplete, but at the same time it indicates means whereby from a system $L$ of logic a more complete system $L^{\prime}$ may be obtained. By repeating the process we get a sequence $L, L_{1}=L^{\prime}$, $L_{2}=L_{1}^{\prime}, \ldots$ each more complete than the proceeding. A logic $L_{\omega}$ may then be constructed in which the provable theorems are the totality of theorems provable with the help of logics $L, L_{1}, L_{2}, \ldots$ Proceeding in this way we can associate a system of logic with any constructive

\footnotetext{
${ }^{26}[\ldots]$ alles Mathematische ist formalisierbar; aber die Mathematik ist nicht durch Ein System erschöpfbar, sondern erfordert eine Reihe immer reicherer Sprachen.

27 See also Feferman (1962) and (1988) where Turing's idea and its development are discussed.
} 
ordinal. It may be asked whether such a sequence of logics of this kind is complete in the sense that to any problem $A$ there corresponds an ordinal $\alpha$ such that $A$ is solvable by means of the $\operatorname{logic} L_{\alpha}$.

Also Zermelo proposed to allow infinitary methods to overcome restrictions revealed by Gödel. According to Zermelo the existence of undecidable propositions was a consequence of the restriction of the notion of proof to finitistic methods (he said here about "finitistic prejudice"). This situation could be changed if one used a more general "scheme" of proof. Zermelo had here in mind an infinitary logic, in which there were infinitely long sentences and rules of inference with infinitely many premises. In such a logic, he insisted, "all propositions are decidable!" 28 He thought of quantifiers as infinitary conjunctions or disjunctions of unrestricted cardinality and conceived of proofs not as formal deductions from given axioms but as metamathematical determinations of the truth or falsity of a proposition. Thus syntactic considerations played no rôle in his thinking.

5. Above the process of the development of the consciousness of the difference between provability and truth in mathematics has been analysed. The rôle of Gödel's incompleteness theorems in this process was stressed and the attempts to overcome the limitations disclosed by those theorems by admitting new infinitary methods (instead of finitary ones only) in the concept of a mathematical proof was indicated. To close this considerations let us note that the very distinction between provability and truth in mathematics presupposes some philosophical assumptions. In fact for pure formalists and for intuitionists there exists no truth/proof problem. For them a mathematical statement is true just in case it is provable, and proofs are syntactic or mental constructions of our own making. In the case of a platonist (realist) philosophy of mathematics the situation is different. One can say that platonist approach to mathematics enabled Gödel to state the problem and to be able to distinguish between proof and truth, between syntax and semantics. $^{29}$

\footnotetext{
${ }^{28}$ Note that that time was not yet ripe for such an infinitary logic. Systems of such a logic, though in a more restricted form than demanded by Zermelo, and without escaping incompleteness, were constructed in the mid-fifties in works of Henkin, Karp and Tarski (cf. Barwise, 1980 and Moore, 1980).

${ }^{29}$ Note that, as indicated above, Hilbert was not interested in philosophical questions and did not consider them.
} 


\section{References}

Barwise, J.: 1980, "Infinitary Logics". In: E. Agazzi (ed.) Modern Logic - A Survey, D. Reidel Publ. Comp., Dordrecht, pp. 3-112.

Carnap, R.: 1934, "Die Antinomien und die Unvollständigkeit der Mathematik", Monatshefte für Mathematik und Physik 41, 263-284.

Carnap R.: 1963, "Intellectual Autobiography". In: Paul A. Schilpp (ed.), The Philosophy of Rudolf Carnap, La Salle, Ill., Open Court Publishing Co., 3-84.

Davis, M. (ed.): 1965, The Undecidable: Basic Papers on Undecidable Propositions, Unsolvable Problems, and Computable Functions, Raven Press, Hewlett, N.Y.

Feferman, S.: 1962, "Transfinite Recursive Progressions of Axiomatic Theories", Journal of Symbolic Logic 27, 259-316.

Feferman, S.: 1984, "Kurt Gödel: Conviction and Causation". In: Philosophia Naturalis, a special issue, P. Weingartner et al. (eds.) Philosophy of Science History of Science. A Selection of Contributed Papers of the rth International Congress of Logic, Methodology and Philosophy of Science, Salzburg, 1983, Meisenheim/Glan (Verlag Anton Hain). Reprinted in: S. G. Shanker (ed.), Gödel's Theorem in Focus, Croom Helm, London 1988, 96-114.

Feferman, S.: 1988, "Turing and the Land of $O(z)$ ". In: R. Herken (ed.), The Universal Turing Machine - A Half-Century Survey, Oxford University Press, New York and Oxford, 113-147.

Frege G.: 1976, Wissenschaftlicher Briefwechsel, Hrsg. G. Gabriel, H. Hermes, F. Kambartel, Ch. Thiel, A. Veraart, Felix Meiner Verlag, Hamburg.

Gödel, K.: 1929, "Über die Vollständigkeit des Logikkalküls", doctoral dissertation; published and translated in: K. Gödel, Collected Works, vol. I, ed. by S. Feferman et al., Oxford University Press, New York and Clarendon Press, Oxford, 1986, 60-101.

Gödel, K.: 1930, "Die Vollständigkeit der Axiome des logischen Funktionenkalküls", Monatshefte für Mathematik und Physik 37, 349-360. Reprinted with English translation "The Completeness of the Axioms of the Functional Calculus of Logic" in: K. Gödel, Collected Works, vol. I, ed. by S. Feferman et al., Oxford University Press, New York and Clarendon Press, Oxford, 1986, 102-123.

Gödel, K.: 1931, "Über formal unentscheidbare Sätze der 'Principia Mathematica' und verwandter Systeme. I", Monatshefte für Mathematik und Physik 38, 173-198. Reprinted with English translation "On Formally Undecidable Propositions of Principia Mathematica and Related Systems" in: K. Gödel, Collected Works, vol. I, ed. by S. Feferman et al., Oxford University Press, New York and Clarendon Press, Oxford 1986, 144-195.

Gödel, K.: 1931?, "Über unentscheidbare Sätze”; first published (German text and English translation "On undecidable sentences") in: K. Gödel, Collected Works, 
vol. III, ed. by S. Feferman et al., Oxford University Press, New York and Oxford $1995,30-35$.

Gödel, K.: 1933, "The Present Situation in the Foundations of Mathematics"; first published in: K. Gödel, Collected Works, vol. III, ed. by S. Feferman et al., Oxford University Press, New York and Oxford 1995, 45-53.

Gödel, K.: 1934, On Undecidable Propositions of Formal Mathematical Systems (mimeographed lecture notes, taken by S. C. Kleene and J. B. Rosser), Princeton; reprinted with revisions in: M. Davis (ed.), The Undecidable: Basic Papers on Undecidable Propositions, Unsolvable Problems, and Computable Functions, Hewlett, N.Y. (Raven Press) 1965, 39-74. Also in: K. Gödel, Collected Works, vol. I, ed. by S. Feferman et al., Oxford University Press, New York and Clarendon Press, Oxford 1986, 346-371.

Gödel, K.: 193?, "Undecidable Diophantine Propositions", first published in: K. Gödel, Collected Works, vol. III, ed. by S. Feferman et al., Oxford University Press, New York and Oxford 1995, 164-175.

Gödel, K.: 1946, "Remarks Before the Princeton Bicentennial Conference on Problems in Mathematics", 1-4; first published in: M. Davis (ed.), The Undecidable: Basic Papers on Undecidable Propositions, Unsolvable Problems, and Computable Functions, Raven Press, Hewlett, N.Y., 1965, 84-88. Reprinted in: K. Gödel, Collected Works, vol. II, ed. by S. Feferman et al., Oxford University Press, New York and Oxford, 1990, 150-153.

Gödel, K.: 1951, "Some Basic Theorems on the Foundations of Mathematics and Their Implications"; first published in: K. Gödel, Collected Works, vol. III, ed. by S. Feferman et al., Oxford University Press, New York and Oxford 1995, 304-323.

Gödel, K.: 1958, "Über eine bisher noch nicht benützte Erweiterung des finiten Standpunktes", Dialectica 12, 280-287. Reprinted with English translation "On a Hitherto Unutilized Extension of the Finitary Standpoint" in: K. Gödel, Collected Works, vol. II, ed. by S. Feferman et al., Oxford University Press, New York and Oxford, 1990, 240-251.

Gödel, K.: 1970, "The Modern Development of the Foundations of Mathematics in the Light of Philosophy"; first published (German text and English translation) in: K. Gödel, Collected Works, vol. III, ed. by S. Feferman et al., Oxford University Press, New York and Oxford 1995, 374-387.

Gödel, K.: 1972, "On an Extension of Finitary Mathematics Which Has Not Yet Been Used", revised and expanded English version of (Gödel, 1958), to have appeared in Dialectica, first published in: K. Gödel Collected Works, vol. II, ed. by S. Feferman et al., Oxford University Press, New York-Oxford 1990, 271-280.

Heijenoort, J. van (ed.): 1967, From Frege to Gödel. A Source Book in Mathematical Logic, 1879-1931, Harvard University Press, Cambridge, Mass. 
Hilbert D.: 1899, Grundlagen der Geometrie. Festschrift zur Feier der Enthüllung des Gauss-Weber-Denkmals, B. G. Teubner, Leipzig, 3-92.

Hilbert D.: 1900, "Über den Zahlbegriff", Jahresbericht der Deutschen Mathematikervereinigung 8, 180-184.

Hilbert, D.: 1901, "Mathematische Probleme", Archiv der Mathematik und Physik 1, 44-63 and 213-237. Reprinted in: D. Hilbert, Gesammelte Abhandlungen, Verlag von Julius Springer, Berlin, Bd. 3, 290-329. English translation: "Mathematical Problems", Bulletin of the American Mathematical Society 8 (1901-2), 437-479; also in: F. Browder (ed.), Mathematical Developments Arising from Hilbert's Problems, Proceedings of the Symposia in Pure Mathematics 28, American Mathematical Society, Providence, RI, 1976, 1-34.

Hilbert D.: 1902/03, "Über den Satz von der Gleichheit der Basiswinkel im gleichschenkligen Dreieck", Proceedings of the London Mathematical Society 35, 50-68.

Hilbert D.: 1903, Grundlagen der Geometrie, second edition, Teubner, Leipzig.

Hilbert D.: 1905, "Logische Principien des mathematischen Denkens", Lecture notes by Ernst Hellinger, Mathematisches Institut, Georg-August-Universität Göttingen, Sommer-Semester 1905. Unpublished manuscript.

Hilbert D.: 1905a, "Über die Grundlagen der Logik und der Arithmetik". In: A. Krazer (ed.), Verhandlungen des dritten Internationalen MathematikerKongresses in Heidelberg vom 8. bis 13. August 1904, Teubner, Leipzig, 174-185. English translation: 'On the Foundations of Logic and Arithmetic' in: J. van Heijenoort (ed.) 1967, From Frege to Gödel. A Source Book in Mathematical Logic, 1879-1931, Harvard University Press, Cambridge, Mass., 129-138.

Hilbert D.: 1917-18, "Prinzipien der Mathematik", Lecture notes by Paul Bernays, Mathematisches Institut, Georg-August-Universität Göttingen, Wintersemester 1917-18. Unpublished typescript.

Hilbert D.: 1918, "Axiomatisches Denken", Mathematische Annalen 78, 405-415. Reprinted in: D. Hilbert, Gesammelte Abhandlungen, Verlag von Julius Springer, Berlin, Bd. 3, 146-177.

Hilbert D.: 1930, "Probleme der Grundlegung der Mathematik", Mathematische Annalen 102, 1-9.

Hilbert, D.: 1930a, "Naturerkennen und Logik", Naturwissenschaften 18, 959-963. Reprinted in: D. Hilbert, Gesammelte Abhandlungen, Bd. 3, Verlag von Julius Springer, Berlin 1935, 378-387.

Hilbert D.: 1931, "Die Grundlegung der elementaren Zahlentheorie", Mathematische Annalen 104, 485-494. Reprinted in: D. Hilbert, Gesammelte Abhandlungen, Bd. 3, Verlag von Julius Springer, Berlin 1935, 192-195.

Hilbert, D., and W. Ackermann: 1928, Grundzüge der theoretischen Logik, Verlag von Julius Springer, Berlin. English translation of the second edition: Principles of Mathematical Logic, Chelsea Publishing Company, New York 1950. 
Hilbert, D., and P. Bernays: (1934/1939), Grundlagen der Mathematik, SpringerVerlag, Berlin, Bd. I 1934, Bd. II 1939.

Köhler, E.: 1991, "Gödel und der Wiener Kreis". In: P. Kruntorad (ed.), Jour Fixe der Vernunft, Hölder-Pichler-Tempsky, Wien, 127-158.

Moore, G. H.: 1980, "Beyond First-Order Logic: The Historical Interplay Between Mathematical Logic and Axiomatic Set Theory", History and Philosophy of Logic $1,95-137$.

Murawski R.: 1998, "Undefinability of Truth. The Problem of the Priority: Tarski vs Gödel", History and Philosophy of Logic 19, 153-160.

Neumann von, J.: 1966, Theory of Self-Reproducing Automata, ed. A. W. Burks, University of Illinois, Urbana.

Rowe, D.E.: 1989, "Klein, Hilbert, and the Göttingen Mathematical Tradition", Osiris (2) 5, 186-213.

Rosser, J.B.: 1937, "Gödel Theorems for Non-Constructive Logics", Journal of Symbolic Logic 2, 129-137.

Tarski, A.: 1930, "Fundamentale Begriffe der Methodologie der deduktiven Wissenschaften. I", Monatshefte für Mathematik und Physik 37, 361-404. English translation "Fundamental Concepts of the Methodology of the Deductive Sciences" in: Logic, Semantics, Metamathematics. Papers From 1923 To 1938, Clarendon Press, Oxford 1956, 60-109.

Tarski, A.: 1933, Pojęcie prawdy w językach nauk dedukcyjnych, Nakładem Towarzystwa Naukowego Warszawskiego, Warszawa.

Tarski, A.: 1936, "Der Wahrheitsbegriff in den formalisierten Sprachen", Studia Philosophica 1, 261-405 (offprints dated 1935).

Tarski, A.: 1954, "Contributions to the Discussion of P. Bernays, Zur Beurteilung der Situation in der beweistheoretischen Forschung", Revue Internationale de Philosophie 8, 16-20.

Tarski, A.: 1956, "The Concept of Truth in Formalized Languages". In: Logic, Semantics, Metamathematics. Papers From 1923 To 1938, Clarendon Press, Oxford 1956, 152-278.

Turing, A.: 1939, "Systems of Logic Based on Ordinals", Proc. London Math. Soc., ser. 2, 45, 161-228.

Wang, Hao: 1974, From Mathematics to Philosophy, Routledge and Kegan Paul, London.

Wang, Hao: 1981, "Some Facts About K. Gödel", Journal of Symbolic Logic 46, 653-659.

Wang, Hao: 1987, Reflections on Kurt Gödel, M.I.T. Press, Cambridge, Mass. 
Wang, Hao: 1996, A Logical Journey. From Gödel to Philosophy, The MIT Press, Cambridge, Massachusetts and London, England.

Woleński, J.: 1989, Logic and Philosophy in the Lvov-Warsaw School, Kluwer Academic Publishers, Dordrecht.

Woleński, J.: 1991, "Gödel, Tarski and the Undefinability of Truth". In: Yearbook 1991 of the Kurt Gödel Society (Jahrbuch 1991 der Kurt-Gödel-Gesellschaft), Wien, 97-108. Reprinted in: J. Woleński, Essays in the History of Logic and Logical Philosophy, Jagiellonian University Press, Kraków 1999, 134-138.

Woleński, J.: 1995, "Mathematical Logic in Poland 1900-1939: People, Circles, Institutions, Ideas", Modern Logic 5, 363-405.

Roman Murawski

Adam Mickiewicz University

Faculty of Mathematics and Computer Science

ul. Matejki 48/49

60-769 Poznań, Poland

rmur@math.amu.edu.pl 